Asian Social Work Journal (ASWJ), Volume 6, Issue 3, (page 13 - 19), 2021

DOI: https://doi.org/10.47405/aswj.v6i3.168

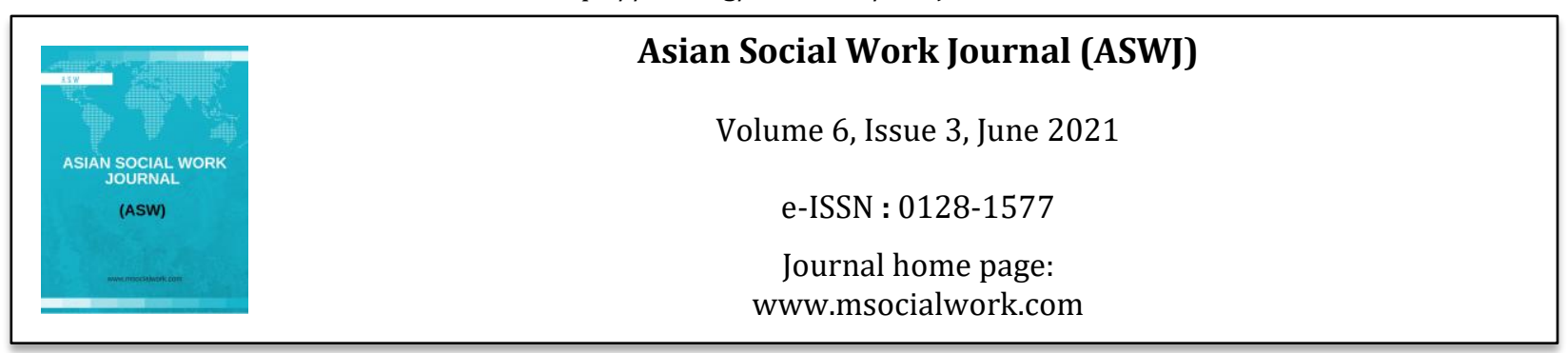

\title{
Social Interaction based on Online Media in the use of Transportation
}

\author{
Chontina Siahaann ${ }^{1}$, Donal Adrian ${ }^{2}$ \\ ${ }^{1}$ Program Studi Ilmu Komunikasi, FISIPOL, Universitas Kristen Indonesia, Indonesia \\ 2Prodi Ilmu Komunikasi, FISIP, Universitas Tadulako, Indonesia \\ Correspondence: Donal Adrian (donal.adrian2014@gmail.com)
}

\begin{abstract}
Online transportation is part of the development of technology that is needed by anyone in carrying out daily activities. This study aims to find out online media-based social interactions in the use of transportation. This research uses qualitative method with observation data collection and in-depth interview. The results showed that the interaction of city people based on online media in using transportation, among others (1) every community is required to be able to use online media, (2) communication conducted in online media discussing about pickup address and destination address, (3) People as consumers can know the amount of payment from the distance traveled through online applications and maps, and (4) the public will give assessment points after receiving transport services online.
\end{abstract}

Keywords: social interaction, media, online transportation

\section{Introduction}

Transportation problems are the hardest situation faced by many developing countries such as Indonesia. Such situations can hinder human productivity in completing various activities both formal and non-formal. The biggest hope of the problems faced in the field of transportation is to utilize communication technology that is able to facilitate users in obtaining transportation. This is certainly different from conventional use of transportation, where users are required to come to the transportation base, negotiate prices and sometimes do not get good service. Furthermore, conventional transportation can certainly be time-consuming because the user has to wait for transportation for hours to get to the place of activity. Furthermore, online transportation such as online transportation can provide a good solution for its users. This is based on the results of research by Anindhita et al (2016:712) explaining that the existence of online transportation turns out to provide solutions and answer various public concerns about public transportation services. The capital's congestion and public fears with the safety of public transportation have been answered by the presence of online transportation that provides convenience and comfort for its users.

Jakarta as the capital city has a large number of people compared to other cities in Indonesia, its people live with a variety of activities that require them to complete it in a faster time so that it can move to another job. No wonder Jakarta is currently a very developed area both in terms of education, offices, international-level companies, the development of the world of television and others. Jakarta is a metropolitan city that requires its people to do activities more deftly and able to show the side of good quality. Therefore, to facilitate all these activities, it takes the use of communication technology that is 


\section{Asian Social Work Journal (ASWJ), Volume 6, Issue 3, (page 13 - 19), 2021 \\ DOI: https://doi.org/10.47405/aswj.v6i3.168}

able to make it easier for people to get online transportation that is also able to answer the problem in big cities, namely congestion.

Transportation problems and congestion that are still widely complained about by all parties become their own homework for many parties not only the government. Moreover, Jakarta was once crowned as the most expensive city in the world. But it turns out that this congestion can even be overcome well due to online transportation.

Crossmedia Link's survey results in (Maylya et al., 2018:1) state that now almost half of Internet users in Indonesia use online transportation applications (Teknojurnal.com, 2017). As of February 2018, there are 3 major non-conventional online transportation players in Indonesia, namely GO-JEK, Uber, and Grab. However, as of Monday, March 26, 2018, Grab officially acquired Uber for the Southeast Asian market (Kompas.com, 2018). There are 3 communication actors in online transportation, namely companies, drivers and passengers. Drivers are the main workers in online transportation, as they are the ones running with their own vehicles and the company supports it with the app (Kangtransportasi, 2018). When viewed from the driver's side there are three kinds of communication formed, namely the driver with the company and vice versa, the driver with the passenger and vice versa, and the driver with fellow drivers (Maylya et al., 2018:1)

The development of technology in supporting human activities to obtain online transportation is part of the development of media communication. People can easily determine the desired vehicle to deliver them to their destination, both by using motorcycles and cars. Through online media, they as service users will follow the instructions of the messages written by the company, starting from the pickup location, the fee to be paid to the destination using maps. The information written is basically very clear to understand. Booking online transportation such as grab also gives service users and drivers the opportunity to communicate with each other in relation to important things such as drivers asking about using clothes of what color? Driver who explains the characteristics of the car and motorcycle used, and so on.

Hafiz et al. (2013) explained that modernization in transportation is a breakthrough for the government to improve the service system in the field of public transportation. Maharani (2017) in Yunus, (2017) explains the rapid development of internet technology causing change in society. Many businesses began to emerge by involving the development of internet technology. One of them is a business in the application-based service provider in the field of online-based transportation mode that turns out to be able to provide solutions and answer various public concerns about public transportation services. Transportation is a very important and strategic means of smoothing the wheels of the economy, strengthening unity and unity and affecting all aspects of the life of the nation and the country.

The use of online transportation services is very useful to support the success of activities carried out both in completing office work, household activities, visiting entertainment venues to relax and so on. The use of this transportation makes people in Jakarta also have a different lifestyle change pattern than before. This pattern will be done continuously using media communication or often referred to as the internet.

\section{Literature Review}

\section{Social Interaction}

Interaction is the process by which people communicate with each other in thoughts and actions. Basically, people in everyday life can not be separated from one another, where the behavior between individuals influences, changes, or improves the behavior of other individuals or vice versa (Setiadi et al. 2003: 95). Gillin and Gillin propose two conditions that must be met in order for a social interaction to occur, namely the existence of social contact and communication (Anwar and Adang 2013: 195). 


\section{Asian Social Work Journal (ASWJ), Volume 6, Issue 3, (page 13 - 19), 2021 \\ DOI: https://doi.org/10.47405/aswj.v6i3.168}

According to Walgito (2003), social interaction is a relationship between one individual and another, one individual can affect another individual or vice versa, so there is a mutual relationship. Social interaction is one of the individual's ways to maintain the social behavior of the individual so that the individual can still behave socially with other individuals. Social interaction can also increase the number or quantity and quality or quality of individual social behavior so that individuals are more mature in social behavior with other individuals in social situations (Santoso, 2010).

Soekanto (2012), suggests that forms of social interaction are (1) cooperation which means a joint cooperation between individuals or groups to achieve a goal, (2) accommodation, as a process in which individuals conflict with each other, then make adjustments to each other to overcome tensions, (3) competition, is defined as a process in which individuals or groups compete for profit through the area of life by attracting attention or sharpening existing prejudices, without resorting to violence or threats, and (4) conflict/opposition, is a social process in which an individual or group seeks to fulfill its objectives by challenging the opposing party with threats or violence.

\section{Media}

In 1990, Mark Poster launched his major book, The Second Media Age, which marked a new period in which interactive technology and network communication, particularly cyberspace, would transform society. There are two dominant views on the difference between the first media era, with its emphasis on broadcasting, and the second media era, with its emphasis on networking (Littlejohn, Foss 2009:413).

Online media is a new type of journalism because it has a number of features and characteristics of traditional journalism. Its unique features are featured in its technology, offering endless possibilities in processing and spreading the word (Septiawan Santana K, 2005:137).

In the Journal of International Communication Mass Society, Mass Culture, and Mass Communication: The Meaning of Mass, by Kurt Lang and Gladys Engel Lang(2009), mention The new media have also affected culture. There has been a far-reaching transformation of the general wayof life, particularly in how people spend their leisure hours and how they take part in celebratory occasions. Traditional folk art and customary recreational activities have been partly replaced by an unprecedented flood of symbolic goods produced for the market or sold to media organizations for dissemination to their audiences. The viability of artistic creations today is less dependent on aristocratic or state patronage than so-called "high" culture had been in the past. Without momentous advances in communication technology, such a transformation would have been inconceivable.

\section{Online Transportation}

Transportation is a very important area of activity in the lives of Indonesians. Recognizing the importance of the role of transportation, traffic and public transportation must be organized in an integrated national transportation system and able to realize the availability of transportation services in accordance with the level of traffic needs and transportation services that are orderly, comfortable, fast, smooth and low cost (Muhammad, 2013:7).

Transportation is defined as the transfer of goods and people from the place of origin to the destination. So with these activities, there are three things, namely the presence of cargo transported, the availability of vehicles as transportation, and the existence of roads that can be traversed. The process of transferring from the movement of the place of origin, where the transport activities begin and to the destination where the activity ends. Therefore, with the transfer of goods and people, transportation is one of the sectors that can support economic activities (the promoting sector) and the servicing sector for economic development (Nasution, 2004:15).

Dagun (2006:126) states that good transportation for public services must meet three basic criteria, namely comfort, safety, and speed. 


\section{Asian Social Work Journal (ASWJ), Volume 6, Issue 3, (page 13 - 19), 2021 \\ DOI: https://doi.org/10.47405/aswj.v6i3.168}

The rapid development of internet technology provides social change of society. Many businesses began to emerge by utilizing the development of information technology, one of which is the emergence of application-based service providers. One of them, is the emergence of online-based transportation modes that can provide solutions and answer various public concerns about public transportation services. The capital's congestion and public fears with the safety of public transportation are answered by the presence of online transportation applications that provide convenience and convenience for its users (Chan, 2017).

With online transportation, passengers now no longer need to approach the ojek base, rickshaws or no longer have to wait by the roadside to get a taxi. In addition, passengers also do not have to be involved in the bargaining process because the fares are predetermined based on mileage. When stuck in traffic on the road, passengers do not have to worry about swollen fares, because the predetermined fare at the beginning of the trip is based on mileage. This lifestyle change is used by businesses to start business competition in the online transportation business (Hangganararas, 2017).

\section{Methodology}

The type of research used is qualitative with the delincatory case studies. According to Miles and Huberman (1992: 1-2) said that qualitative data is very interesting. Qualitative data is the source of a broad and solid description, and contains an explanation of the processes that occur in the local sphere. With qualitative data we can follow and understand the flow of events in chronological order, assess causation within the scope of the minds of local people and obtain many and useful explanations. And while more qualitative data can lead researchers to obtain unexpected discoveries beforehand and to form new theoretical frameworks, they help researchers to go further than the initial presumptions and frameworks.

The data collection techniques in qualitative research are based on two, namely: Interviews are open and flexible conducted in an informal and intimate atmosphere (Nasution, 1992: 69-81). The purpose of the interview was affirmed by Guba and Lincoln (in Moleong, 2007:186) among others to construct, reconstruct, project and verify research objects and (b) Observations were made not only to record an event or event, but also to do everything or as many things as it is suspected to have something to do (Nasution, 1992: 58).

Data analysis in the view of Miles and Huberman (1992: 1-2) that consists of three flow of activities that occur simultaneously, namely: data reduction, data presentation, and conclusion / verification. Here's an explanation of the data analysis of Miles and Huberman:

\section{i. Data Reduction}

Data reduction is defined as the process of selecting, focusing on simplification, abstraction and transformation of "rough" data that arises from written records while in the field. Data reduction runs continuously during qualitatively oriented projects. During data collection there is a further stage of reduction (creating summaries, coding, tracing themes, creating clusters, creating partitions and creating memos). The reduction of data or transformation process takes place after field research, until the final report is compiled. Data reduction is a form of analysis that sharpens, classifies, directs, discards unnecessary and organizes the data in such a way that the final conclusions can be drawn and verified.

\section{ii. Display Data}

The second important flow in the study is the presentation of data. Miles and Huberman limit a "presentation" as a set of structured information that allows for conclusion and action. Data presentation can be done in the form of tables, graphs, matrices, networks and charts. All of them are designed to combine information composed in a form that is on and easy to achieve, thus an analyst can see what is going on, and determine whether to draw the correct conclusions 
or continue to do analysis that according to the advice presented as something that may be useful.

\section{iii. Conclusion Drawing / Verification}

The third important analysis activity is to draw conclusions and verify. From the beginning of data collection, researchers began to look for the meaning of objects and record regularity, patterns, explanations, causal flows, and propositions. Competent researchers will handle those conclusions loosely, remain open and skeptical, but the conclusions already provided, at first unclear, then increase in detail and firmly root. The "final" conclusion may not appear until the data collection is concluded, depending on the size of the sets of field records, coding, storage, and money-seeking methods used, but that conclusion has been formulated from the beginning. The withdrawal of conclusions is simply an activity of a complete configuration. Conclusions are also verified during the study. In short, the meanings that arise from the data must be tested for correctness, compatibility, which is validation.

\section{Discussion}

The tendency of social change is a natural symptom arising from the association of human life in society. Social changes will continue and continue to occur due to changes in elements that maintain the balance of society, such as changes in the element of interaction through communication. Nowadays, people are very easy to communicate with anyone either in known or unknown individuals and have never met before. Through the development of communication technology, in a matter of minutes and even seconds, people can communicate faster over the internet. Individuals can interact with each other, can exchange messages and can understand their intentions and goals. The success of sending and receiving messages in social interactions is largely determined by the actors of communication that influence each other.

According to Walgito (2003), social interaction is a relationship between one individual and another, one individual can affect another individual or vice versa, so there is a mutual relationship. Social interaction is one of the individual's ways to maintain the social behavior of the individual so that the individual can still behave socially with other individuals. Social interaction can also increase the number or quantity and quality or quality of individual social behavior so that individuals are more mature in social behavior with other individuals in social situations (Santoso, 2010).

In the modern era as it is today, almost all people interact with using online media. This is a necessity of life because it can speed up the work process and not use a lot of time. The use of online media can be enjoyed through smartphones owned by each individual. They can be blessed easily and certainly productively. For example in the use of online transportation that can be disorder anywhere and anytime. This is the benefit of online media for everyday life.

Social changes caused by communication technology experienced by people in big cities such as Jakarta certainly have a huge benefit in carrying out any activity. The use of new media can speed up the work process especially with regard to online transportation that can be ordered through the use of smartphones. Ward (1995:279) says that new media is effective without mediation because it can be used directly without going through complex media organizations like old or traditional media organizations. As stated more clearly by Mc Quail (2000:119) where most of these new media allow interactive two-way communication that allows the collection and delivery of information so that the implications can vary. In the Journal of International Communication Mass Society, Mass Culture, and Mass Communication: The Meaning of Mass, by Kurt Lang and Gladys Engel Lang(2009), mention The new media have also affected culture. There has been a far-reaching transformation of the general wayof life, particularly in how people spend their leisure hours and how they take part in celebratory occasions. Traditional folk art and customary recreational activities have been partly replaced by an unprecedented flood of symbolic goods produced for the market or sold to media organizations for dissemination to their audiences. The viability of artistic creations today is less dependent on 
aristocratic or state patronage than so-called "high" culture had been in the past. Without momentous advances in communication technology, such a transformation would have been inconceivable.

Modernization is a form of transformation of traditional society into a modern society that has been exposed to technology. The rapid development of internet technology provides social change of society. Many businesses began to emerge by utilizing the development of information technology, one of which is the emergence of application-based service providers. One of them, is the emergence of online-based transportation modes that can provide solutions and answer various public concerns about public transportation services. The capital's congestion and public fears with the safety of public transportation are answered by the presence of online transportation applications that provide convenience and convenience for its users (Chan, 2017).

With online transportation, passengers now no longer need to approach the ojek base, rickshaws or no longer have to wait by the roadside to get a taxi. In addition, passengers also do not have to be involved in the bargaining process because the fares are predetermined based on mileage. When stuck in traffic on the road, passengers do not have to worry about swollen fares, because the predetermined fare at the beginning of the trip is based on mileage. This lifestyle change is used by businesses to start business competition in the online transportation business (Hangganararas, 2017).

Based on the findings of the study shows that the social interaction of people based on online media in the use of online transportation is (1) every community is required to be able to use online media, (2) communication conducted in online media discussing about pickup address and destination address, (3) People as consumers can know the amount of payment from the distance traveled through online applications and maps, and (4) the public will give assessment points after receiving transport services online.

Social changes caused by communication technology experienced by people in big cities such as Jakarta certainly have a huge benefit in carrying out any activity. The use of new media can speed up the work process especially with regard to online transportation that can be ordered through the use of smartphones. Ward (1995:279) says that new media is effective without mediation because it can be used directly without going through complex media organizations like old or traditional media organizations. As stated more clearly by Mc Quail (2000:119) where most of these new media allow interactive two-way communication that allows the collection and delivery of information so that the implications can vary.

\section{Conclusion}

Based on the results of existing research, the conclusion shows that modernization is part of people's lives that interact not only directly but can be done by media, such as social interaction in using online transportation. Online media-based interactions include: (1) every community is required to be able to use online media, (2) communication conducted in online media discussing about pickup address and destination address, (3) People as consumers can know the amount of payment from the distance traveled through online applications and maps, and (4) the public will give assessment points after receiving transport services online.

\section{References}

Anindhita, Wiratri, Melisa \& Devie (2016). Analisis Penerapan Teknologi Komunikasi Tepat Guna Pada Bisnis Transportasi Transportasi Online (Studi pada Bisnis Gtransportasi dan Grab Bike dalam Penggunaan Teknologi Komuniasi Tepat Guna untuk Mengembangkan Bisnis Transportasi). Prosiding Seminar Nasional INDOCOMPAC Universitas Bakrie, Jakarta. 2-3 Mei 2016

Anwar \& Adang. (2013). Sosiologi untuk Universitas. Bandung: PT Refika Aditama. 
DOI: https://doi.org/10.47405/aswj.v6i3.168

Chan, Arianis. Dkk. (2017). Perbandingan Pengalaman Pengguna pada Aplikasi Mobile Go-Jek dan Grab (Studi pada Konsumen PT. Go-Jek dan PT. Grab Indonesia di Dki Jakarta).Jurnal AdBispreneur Vol.2, No.2, 164.

Dagun, S. M. (2006). Busway, Terobosan Penanganan Transportasi Jakarta.Jakarta: Pustaka Sinar Harapan.

Hangganararas, S. (2017). Analisis Kelayakan Layanan GO-JEK Sebagai Moda Transportasi di Yogyakarta.Yogyakarta: Universitas Atma Jaya

Kurt Lang \& Gladys Engel Lang (2009) The Meaning of Mass. http://ijoc.org/ojs/index.php/ijoc/article/view/597/407

Littlejohn, Stephen W., and Karen A. Foss. (2009). Theories Of Human Communication $9^{\text {th }}$ Edition. Belmont: Thomson Wadsworth.

Maylya, Gatut \& Lady. (2018). Pola-pola Komunikasi dalam Komunitas Virtual Pengemudi Transportasi Online. JURNAL E-KOMUNIKASI. VOL 6. NO.2 TAHUN 2018

Mc Quail, Dennis. 2000. Mc Quail's CommunicationTheory (4 ${ }^{\text {th }}$ edition). London: Sage Publications.

Mc Quail, Dennis. 2002. Media Perfomance: Mass Communication and the Public Interest. London: Sage Publications.

Miles, Matthew B, dan Huberman, A. Michael. (1992). Qualitative Data Analysis. (Terjemahan: Tjetjep Rohendi dengan judul: Analisis Data Kualitatif), UI-Press: Jakarta

Moleong, Lexy. (2007). Metode Penelitian Kualitatif. Remaja Rosdakarya: Bandung

Nasution, S. (1992). Metode Penelitian Naturalistik Kualitatif. Bandung, Tarsito, 1992.

Nasution, M. (2004). Manajemen Trasnportasi.Jakarta: Ghalia Indonesia.

Muhammad, A. (2013). Hukum Pengangkutan Niaga.Bandung: Citra Aditya Bakti.

Santana K, Septiawan, (2005). Jurnalisme Kontemporer, Jakarta: Yayasan Obor Indonesia.

Santoso, S. (2010). Teori-teori psikologi sosial. Yogyakarta: Reflika Aditama

Setiadi EM, Hakam KA \& Effendi R. (2013). Ilmu Sosial Budaya Dasar. Jakarta: Kencana.

Soekanto, S. (2012). Sosiologi Suatu Pengantar. Jakarta: Rajawali Pers

Walgito, B. (2003). Psikologi Sosial Suatu Pengantar. Yogyakarta: Andi Offset

Ward, Ian. (1995). Politics of the Media. Melbourne: Mac Milan 